\title{
Yosef ben Mordekhay Malinowski: On the Date of his Death
}

\author{
Piotr Muchowski \\ Adam Mickiewicz University \\ Arie Yariv \\ Tel Aviv University
}

\begin{abstract}
According to Jacob Mann, Yosef ben Mordekhay Malinowski, a prominent pupil of Yișhaq ben Avraham of Troki, died after 1624. This article quotes some new data on the date of his death and proves it should be established within a few years after 1603. It points out that most probably Malinowski left Troki and moved to Łuck in 1602. The article also gives a brief genealogy and a list of his works.
\end{abstract}

\section{Keywords}

Yosef ben Mordekhay Malinowski (Joseph ben Mordecai Malinowski), Yiṣhaq ben Avraham of Troki (Isaac ben Abraham of Troki), Polish-Lithuanian Karaites, Karaites in Troki, Karaites in Birże

Yosef ben Mordekhay Malinowski is one of the best-known Karaite scholars from Lithuania at the turn of the $16^{\text {th }}$ and $17^{\text {th }}$ centuries. He was a student of the famous Yiṣhaq ben Avraham of Troki, who entrusted him with the completion of Hizzuq 'Emuna. ${ }^{1} \mathrm{He}$ also authored numerous works. The most known of them are Sep̄er ha-'Elep Leka (Šelomo), ${ }^{2}$ Qișșur Inyan haš-Šehita ${ }^{3}$ and Seper Minhagim, ${ }^{4}$ which appeared in print. Moreover, his oeuvre includes a

${ }^{1}$ See the introduction to Hizzuq 'Emuna by Yosef ben Mordekhay (Haqdamat Talmid ham-Mehabber).

2 Edited by Menashe ben Israel in Amsterdam, 1643.

3 This treatise is also known under the title Qișșure haš-Šehitot, based on 'Adderet 'Eliyyahu. Edited in Wien, 1830, cf. [MaLINowski] 1830.

4 Edited in Siddur hat-Tefillot haq-Qara'im in Wilno, 1891, cf. SzYszman 1891: 457-464. 
number of works of poetry ${ }^{5}$ and commentaries to various passages of 'Adderet 'Eliyyahu ${ }^{6}$ and Tokahat 'aken yeš li-hida.

Simḥa Łucki (Luṣqi/Lutski) gives the following description of his literary output in Ner Saddiqim: ${ }^{2}$

"The prominent scholar, divine philosopher, rav ribbi Yosef, son of the honourable sir rav Mordekhay, the martyr, may the Lord avenge his blood, was a student of rav ribbi Yișhaq, mentioned above, righteous of blessed memory. He wrote an excellent explanation and esteemed commentary to 'Eśer 'Iqqarim in the 'Adderet book. In addition to this, he wrote an excellent and profound commentary on 'Arayot in the 'Adderet book. Moreover, he wrote a summary of 'Inyan haš-Šehita in the 'Adderet book. What is more, he wrote

5 אל נערץ בסוד בקדושים רבה: Szyszman 1892b: 83-84; Schocken Institute for Jewish Research 13555, 127v-130v; Bodleian Library 2777, 2r-3r; Abk 3, 180v-182v;

'אפיל תחנתי לפני ה' BeZEkowicz and Firkowicz 1909: 20; NLI (the National Library of Israel) Heb. $8^{\circ} 5195$, 41r-41v;

מאסר העוף ותפישתו: Mann 1935: 1228-1231; NLI Heb. 8º5204, 108v-109v; (the Karaite

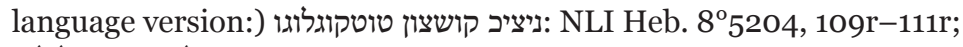

אזכיר תהלות נורא עלילות: NLI Heb. $8^{\circ} 5204$, 80r-80v; JSul.III.5, 560r-560v;

יה שמע קולי ורחם : NLI Heb. $8^{\circ} 3795$, 42r; NLI Heb. $8^{\circ} 5204$, 25r;

ישתבח אל עליון: Abk 1 (no pagination); JSul.III.79, 16or;

איכה אפתח שפתי: Abk 3, 214r-216v; Abk 3, 157v-[158v];

אבוא ביתך בפחד וחרדה: JSul.III.79, 254r;

אדם בולינכ כי : אנעים קולי לפני אלי קופרקסין: NLI Heb. $8^{\circ} 5204,148 r-149 r ;$

קיסקא ווגדייני צנים בילימוסין: NLI Heb. 8º5195, 24v;

בלשון ראש עבר: Abk 3, 342v, 10-18;

עורי יחידה משנת אולת: BNU (Bibliothèque Nationale et Universitaire, Strasbourg ) 3974: 168r; אכונן דברי ואמתיק זמירי :NLR Evr II a 156-1, 7r-8v; NLR Evr II a 5, 94r; Russian State Library, Moscow, Schneerson Collection, Evr 225, 2r-2v (with an introduction, הקדמה, to Minhat Yehuda. Cf. MANn 1935: 732).

6 Among others to 'Aśara 'Iqqarim, Šabbat, Seder Našim, Mila, etc. Cf. NLR Evr I 664, 1r-31v; JTS (Jewish Theological Seminary) 3459, 303r-323v; JTS 3359, 70r-81v; BNU 3974, 89r-116v; Abk 3, 331v, 1-332v, 6; 341r, 4-341r, 13.

7 Cf. Szyszman 1892a: 22-23. IOM (the Institute of Oriental Manuscripts of the Russian Academy) C 74, 3r-3v; IOM B 415, 5v-6v; IOM C 74, 3r-3v; NLI Evr II a 156-1, 4v-6v.

8 Ner Saddiqim, chapter 10; cf. Mann 1935: 1431 (HUC Ms 849, 137v (227v)):

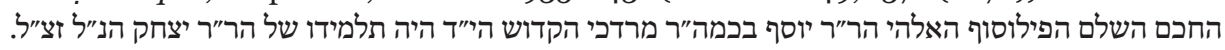

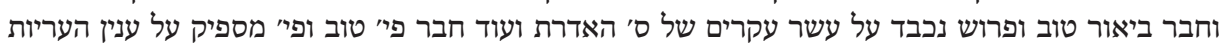

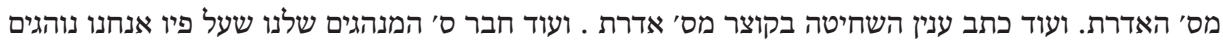

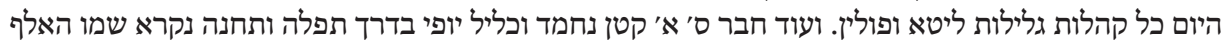

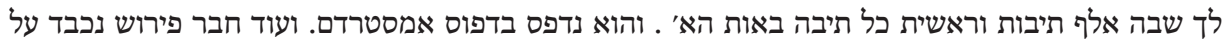

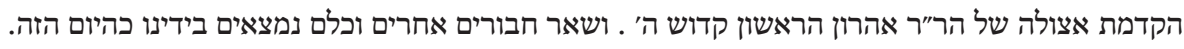


our book Minhagim, according to which we, all communities of the Lithuanian and Polish areas, act today. Moreover, he wrote a pleasant small book, perfect in its beauty, in the manner of prayer and plea, called Ha-'elep leka, which consists of a thousand words, each word begins with he. It was published in Amsterdam. Apart from that, he wrote an esteemed commentary to Haqdamat 'așula of rav ribbi Aharon the First, ${ }^{9}$ saint of the Lord. And other works. All of them have been in our hands until today."

Yosef ben Mordekhay Malinowski was a member of one of the most distinguished Lithuanian Karaite families, i.e. the branch of the Malinowski family descended from the shofet (Pol. wójt) "Pan Jesko" (Sir Jesko) ${ }^{10}$. He was a grandson of Yosef, shofet, son of Mordekhay, rofe and shofet ${ }^{11}$ (it is not clear when he held the position of the shofet). It is known that his grandmother Esther, daughter of Nisan (wife of Yosef the shofet) came from Łuck (died in 1590). Yosef was born to the marriage of Mordekhay haq-qadosh ben Yosef and Malka. His parental uncle was Avraham, the shofet (father of nine sons; he held the position of the shofet at the beginning of the $17^{\text {th }}$ century $\left.{ }^{12}\right)$. Despite the fact that Yosef ben Mordekhay was married, it is likely that he died childless (with no male descendant in any case). Yosef ben Mordekhay was buried in Łuck. ${ }^{13}$

To date, Yosef ben Mordekhay Malinowski's biography has been best described by Jacob Mann (cf. ManN 1935: 718-720). However, the exact dates of his birth and death are unknown. According to the widely accepted findings of Jacob Mann, Yosef ben Mordekhay died after 1624 and was born about 1570.

In this article, we quote some data from the manuscripts in the Firkowicz collection which allow for a revision of Jacob Mann's findings and a more precise determination of the dates of his birth and death.

\footnotetext{
9 We were not able to find this work of Yosef ben Mordekhay Malinowski. Por. SzYszman 1891: 166; MANN 1935: 446-447, note 2.

${ }^{10}$ Probably Jesko Morduchajewicz, the shofet about mid- $16^{\text {th }}$ century, cf. Mann 1935, 611; GĄSIOROWSKI 2008: 459; the Wróblewski Library of the Lithuanian Academy of Sciences F301-20, 1-4.

${ }^{11}$ Another student of Yișhaq ben Avraham of Troki, Yoshiyahu ben Yehuda, was also a great-grandson of Mordekhay, rofe and shofet, son of Yosef, a shofet, cf. AвRAHAM FirkowICZ's notes in NLR F 972 no. 130, fol. 14v; NLR Evr II A 161-2 fol. 14r.

${ }^{12}$ Cf. Mann 1935: 619; Gąsionowski 2008: 461-462.

${ }^{13}$ Cf. Evr II a 161-2, 1r; SzYszman 1891: 459 (Sep̄er Minhagim); Mann 1935: 720.
} 
The first record is a fragment in the manuscript Seper ha-Rep̄u'ot (NLR Evr I 732) of Avraham ben Yoshiyahu (1636-1687) about his son Yosef, later hazzan in the Nowe Miasto community, who was born in 1666. The fragment reads as follows:

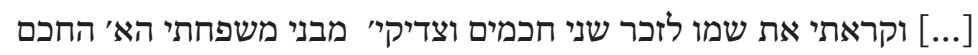

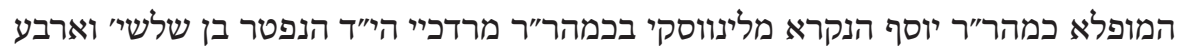

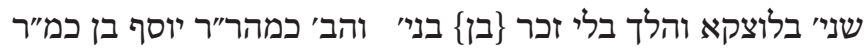

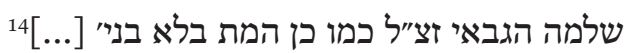

"[...] And I gave him a name in remembrance of two scholars and righteous men who were members of my family. The first one is the notable scholar, honourable sir, rav ribbi Yosef, called Malinowski, son of the honourable sir rav ribbi Mordekhay, may the Lord avenge his blood, who died at the age of 34 in Łuck and passed away leaving no sons to commemorate him. The other one is the honourable sir rav ribbi Yosef, son of the honourable ribbi Shelomo, the gabbay, may the memory of the righteous one be blessed. He also died leaving no sons [...]."

The information in Avraham ben Yoshiyahu's note that Yosef ben Mordekhay died at the age of 34 was previously unknown. It seems perfectly reliable as it comes from a son of Yoshiyahu ben Yehuda (1588-1663), who was Yișhaq ben Avraham's student, like Yosef ben Mordekhay, and was written in 1666. It is worth noting that the manuscript Seper ha-Repu'ot is an autograph. This is extremely significant, as the reliability of the document that casts doubt on Jacob Mann's finding that Yosef ben Mordekhay Malinowski died after 1624 cannot be questioned on the basis of a corrupted text or other reasons.

The approximate date of Yosef ben Mordekhay's death, i.e. after 1624, established by Mann was based on Noah ben Yeshaya's letter marked in his edition with accession no. 124 (= NLR Evr I Dok II, 49). ${ }^{15}$ This letter was sent to Yosef ben Mordekhay Malinowski by Noah ben Yeshaya, melammed and shohet in Birże (or Birżes), who had most likely moved to the town with a group of Troki Karaites. The town belonged to the Lithuanian Prince Krzysztof Radziwilł at

\footnotetext{
${ }^{14}$ Cf. NLR Evr I 732, fol. 56r. See fig. 1.

${ }^{15}$ Cf. Mann 1935: 1196-1198.
} 
that time. ${ }^{16}$ The following date can be found in this letter: Sunday, $25^{\text {th }} E y$ tanim (i.e. Tishri) 385 according to the short count. ${ }^{17}$ It must be emphasised that this is the only dated document quoted by Mann which mentions Yosef ben Mordekhay Malinowski. However, the examination of the note in the manuscript NLR Evr II a 49, fol. 1v (see fig. 2) on which Mann's edition was based, calls this finding into question. It can be clearly seen that the year was added by a different hand (i.e. not by Noah ben Yeshaya), probably the same which added the note beginning with words אלו אגרות on the margin (we suppose, it might be the hand of Gabriel, Abraham Firkowicz's son-in-law). Doubtlessly, the year 385 was added according to the calendar of new moons for 384 and 385 , which are on the left side (see fig. 2). Contrary to Mann's statement (cf. MANN 1935: 1198), the notes were not written by Noah ben Yeshaya's (they are written in different hand-writing, a cursive style known from Constantinople, and were possibly added about 1624 on the reverse side of the folded letter $)^{18}$. It is not known whether a year was included in the date in the letter at all, or if it was illegible and was added for this reason. The above findings are confirmed by Abraham Firkowicz's note about the manuscript Evr I Dok II, 49 from the mid- $19^{\text {th }}$ century, in which he pointed out that the letter originated in 363 , or later:

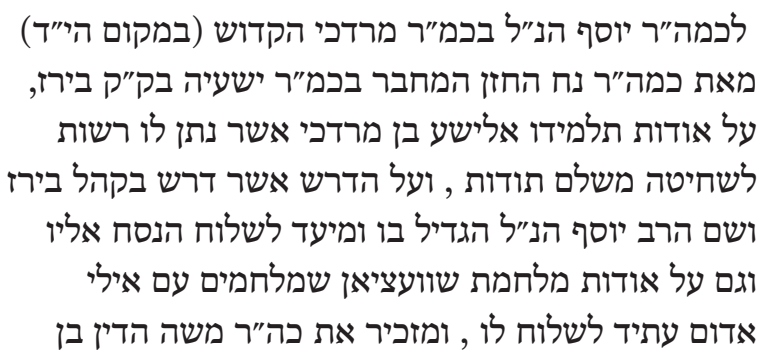

${ }^{16}$ It is likely that the Karaite community in Birże developed some time after 1589 when King Sigismund III Vasa granted special privileges to the inhabitants of the town which exempted them from paying tolls and customs for 25 years. Cf. BARDACH 1990: 199.

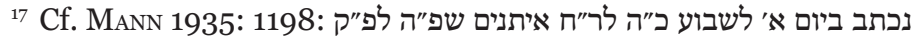

${ }^{18}$ The same hand is found in the manuscript Evr II A 439 which includes a sermon (derash) given in Luck in 1635, cf. folio 3 recto (the name of the preacher and the copyist was not noted; perhaps it is the hand of Ișhaq ben Simha, cf. Mann 1935: 718). The list of new moons in Evr I Dok II 49, 1 verso was probably based on the calculation guidelines sent by Josef Delmedigo to Zarah ben Natan, cf. FünN 1867-1868, Mann 1935: 678. Delmedigo exemplified them with the year 1624 (5384/5385). 


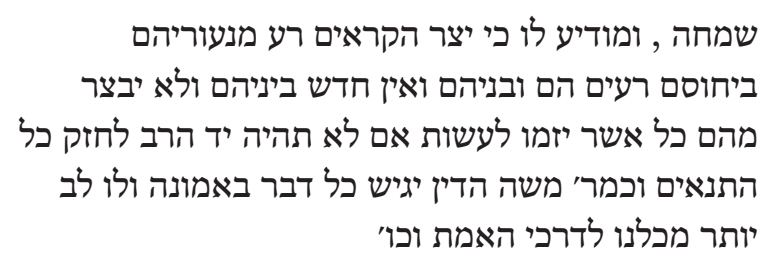

On the right margin: $4{ }^{19}{ }^{19}$ שס"ג או יות

\begin{abstract}
"To the honourable sir rav Yosef, mentioned above, son of the honourable sir ribbi Mordekhay, the martyr (instead of: may the Lord avenge his blood) from the honourable sir, rav Noah, hazzan, author, son of honourable sir ribbi Yeshaya in the holy community of Birże, regarding his student Elisha ben Mordekhay, who gave him the licence to practice as a ritual slaughterer. He is thanking him. On the sermon (derash) which he gave in the community of Birzie. There he raised the above-mentioned rav. He intends to send him the text. Also [one] about the war against the Swedes who are fighting with the hetmans of Edom he is to send him. He mentions the venerable rav Moshe, the dayyan, ben Simha, and informs him that the Karaites' inclination has been evil since their youth and they and their children have been evil for generations. There is nothing new among them; they succeed in nothing they undertake unless the rav has a hand in strengthening all arrangements. The honourable sir ribbi Moshe, the dayyan will present each case truly. Among us all, his heart is the biggest heart for the paths of truth, etc.

On the margin: $4 \cdot 363^{20}$ or later."
\end{abstract}

The mention of the war against Sweden is important for the determination of the actual date the letter was written. Noah ben Yeshaya writes:

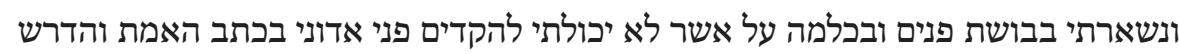

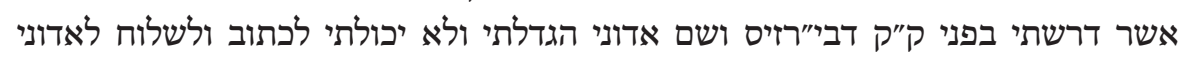

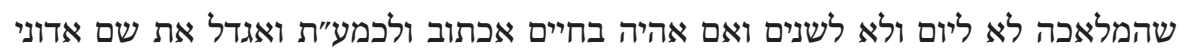

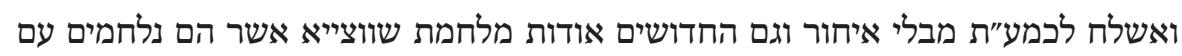

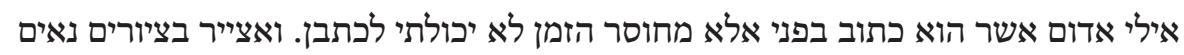

\footnotetext{
${ }^{19}$ Evr 946 no. 130, fol. 4r.

${ }^{20}$ I.e. 1603 in the Gregorian calendar.
} 


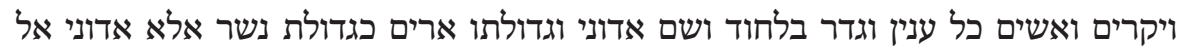

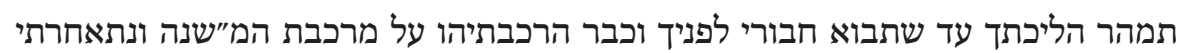

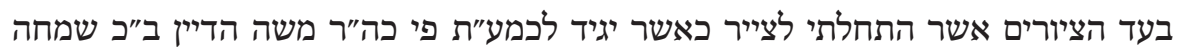
יעמ"ש אשר אני דר בבית כ"מ.

"I was left shamefaced and in dishonour because I did not manage to welcome you, my sir, with 'The writing of truth and the sermon (derash), which I preached before the holy community of Birże. I exalted the name of my sir. Yet I did not manage to write it and sent it to my sir as this work cannot be done in a day or two. And if I stay alive, I shall write to the honourable sir and exalt the name of my sir. I will send it to the honourable sir without delay. Also news about the war against the Swedes who are fighting with the hetmans of Edom, which is written in front of me, but I was unable to write it for the lack of time. I shall draw in nice and valuable pictures and present each matter separately. And I will exalt the name of my sir, like the greatness of the eagle. Only, do not hurry to go on your way, sir, until my writing reaches you. I have already made a rough copy but I have a delay because of the pictures I began to draw, of which you will be informed by the mouth of the venerable Moshe, the dayyan, son of the venerable Simha, may he rest on his bed in peace, the honourable sir whose house I dwell in."

We learn from the letter that the war against the Swedes was taking place at the time it was written. Mann presumed the letter was dated to 1624 and assumed that it was the Third Swedish War of 1621-1629 (Mann 1935: 1196). Yet for obvious reasons, if we rely on Avraham ben Yoshiyahu's information that Yosef ben Mordekhay died at the age of 34, we should assume that it is rather the Second Swedish War of 1600-1611.

In the date in Noah ben Yeshaya's letter (Evr I Dok II 49, fol. 1v) only the year was corrected. The day of the week and the month seem authentic, they are: "Sunday, 25 Eytanim (Tishri)" (see fig. 2). In the Rabbanite calendar, 25 $5^{\text {th }}$ Tishri was on a Sunday only in 1601 (362) and 1608 (369) during the war of 1600-1611. Unfortunately, the data available to us are not sufficient to determine the Karaite calendar at the period in question.

${ }^{21}$ Cf. Mann 1935: 1196-1197; Evr I Dok II 49, fol. 1 r. 
Doubtlessly, the date of Yiṣhaq ben Avraham of Troki's death serves as an important premise for resolving the question of the date of the letter as well. It is known that when he died, Yosef ben Mordekhay, his student, was a young man, probably around 20 years of age. Geiger established that Yișhaq ben Avraham died in 1594 (cf. Geiger 1853: 38, 44). Geiger based this date on the information in Sep̄er 'Elim (Zarah ben Natan's first letter to Yosef Delmedigo), where we read:

ותבוא בת שבע אל המלך שלמה

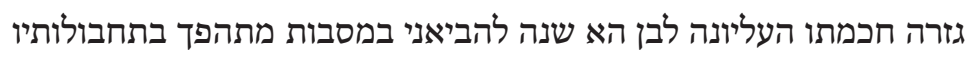

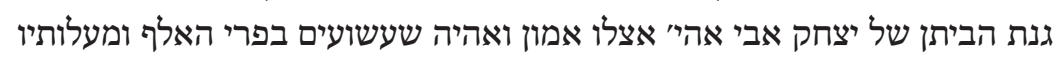

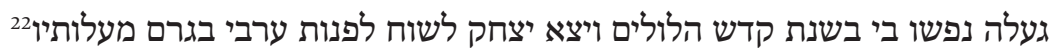

"And Bathsheba went in unto Shelomo. His highest wisdom decided when I was five years old, to bring me turning around and round by his guidance (Job 37:12) in the palace garden of Yișhaq, my father let me be beside him, a master craftsman, let me be a delight (Prov. 8:30), for the fruit of his thousand (Song of Sol. 8:11) and of his upper chambers (Amos 9:6). His soul rejected me in the year 'an offering of praise' (Lev. 19:24). Yișhaq went out to pray (Gen. 24:63) towards evening in his upper chambers.”

The date of birth was read by him from the words קדש הלולים 23, according to the numerical value of the last letters in both words (קדש הלולים =354). It is worth emphasising that 1594 as the date of Yișhaq ben Avraham's death was also found in Mordekhay ben Nisan's note in Dod Mordekay (in the 1714 edition). ${ }^{24}$ Mann questioned Geiger's reading of the date from קדש הלולים. He pointed out that no diacritical marks had been preserved above the relevant letters and emphasized some other data from Zarah ben Natan's letter, i.e. the author's statement that he was 40 years at the time the letter was written (the letter contained the internal date of 380 , i.e. $1620^{25}$ ) and that 32 years had passed since the death of Yișhaq ben Avraham from Troki. Mann assumed that the diacritical marks for the numerical value were contaminated and initially were not placed

\footnotetext{
${ }^{22}$ The Odessa edition from 1864: 3 .

${ }^{23}$ This term also has the meaning of the fourth year, cf. LEV 19:24.

24 Wolfius and Triglandii 1714: 150: זמן פטירת המחבר ע"ה שנת שנ"ד לאלו.

25 נכתב ביום בית ויא' לאייר ויום כ"ג למספר שנת שף לעלמו, Sep̄er 'Elim, the 1864 Odessa edition, p. 3.
} 
above the last two letters in the two words קדש הלולים. He put forward the thesis that Yiṣhaq ben Avraham from Troki died in 1586, in accordance with the information in Zarah ben Natan's letter stating that 32 years had passed between the date of his death and the writing of the letter, i.e. $1618 .{ }^{26}$ Mann established the year to be 1618 by modifying the date 1620 to make it correspond with the numerical value of the letters in קדש הלולים (he assumed it was possible that the relevant paragraph referred to an earlier period). He deemed the details in Dod Mordekay, which was created dozens of years later (late 160os), unreliable as they contradicted the information from Zarah ben Natan, who was Yiṣhaq ben Avraham's student and a witness to his death. Mann accordingly established that Zarah ben Natan was born eight years before Yișhaq ben Avraham's death, that is, in 1578 (cf. MANN 1935: 726-727). It is noteworthy here that like Mann, Simha Łucki established that Yiṣhaq ben Avraham died in 1588, apparently by deducting 32 from 1620, which is the supposed date of the first letter from Zarah ben Natan to Yosef Delemedigo. ${ }^{27}$

In spite of the fact that most researchers accept the date established by Geiger, the dispute described here still seems unresolved. The controversy is evident in, for example, the entry about Yișhaq ben Avraham of Troki in Encyclopaedia Judaica (by Leon Nemoy), which gives the year 1594 as the date of his death; however, provides it with the remark that: "according to Mann's hypothesis, he was born and died eight years earlier than the above dates". ${ }^{28}$ Similarly, the entry about Zarah ben Natan (by Golda Akhiezer, the second edition of 2007), dates his birth to $1578,{ }^{29}$ and thus repeats the supposed date of Yișhaq ben Avraham's death in 1586 after Mann. In regard to the discussed debate, we would

\footnotetext{
${ }^{26}$ Cf. Sep̄er 'Elim (Odessa 1864, p. 4): זה שלשים וב' שנה אחרי מות יצחק אבי והנני בן הכות ארבעים זלעפה אחזתני על אסיפת הורי ומורי...

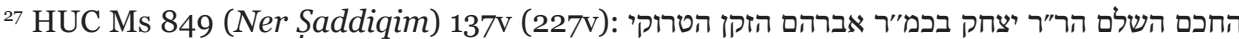

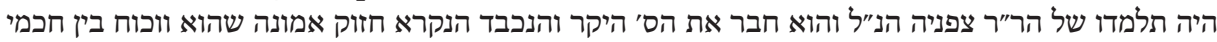
ישראל ובין חכמי הנוצרים ונחלק לשני חלקים וכל חלק לפרקים רבים . וחברו בסוף ימיו בשנת שנת ששי|ם לחיות לחייו ונפטר בשנת השמ"ח לפ"ג.

"The esteemed scholar rav ribbi Ișhq ben Avraham, the elder, of Troki, was a student of rav ribbi Sefanya, mentioned above. He wrote a valuable and venerable book called Hizzuq 'Emuna, which is a discussion between Jewish and Christian scholars. It is divided into two parts, and each part into many chapters. He wrote it at the end of his days, in the $60^{\text {th }}$ year of his life. He died in 5348 according to the long count”.

${ }^{28} \mathrm{Cf}$. Nemoy 2007.

${ }^{29} \mathrm{Cf}$. Komlosh, AkHiezer 2007.
} 
like to mention two premises in the manuscripts of the Firkowicz collection which were not noticed by Mann. Firstly, the NLR Evr I 728 Derushim manuscript includes sermons preached by Yiṣhaq ben Avraham from Troki, and one of them is dated $1592 .{ }^{30}$ Secondly, the Evr I Dok II 59-64 manuscript includes Zarah ben Natan's work, and there is a clear reference to the date of Yișaq ben Avraham's death in the work entitled "Ve-ze hibbur Zarah ben ribbi Nat[an]", marked with no. 28.59. The following passage can be found in lines 12-15:

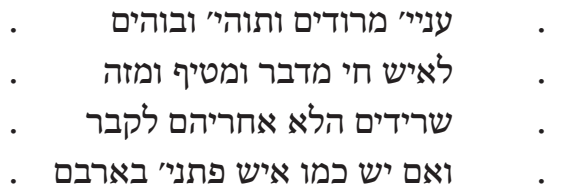

"[...] Remember, o Lord, the one who is among the highest, poorest and homeless ${ }^{31}$. Amazed and astonished.

Their faces fall when they see me.

It is to the alive man I speak, preach and sprinkle (with water).

And (so) since $354,{ }^{32}$ according to the short count. There has been no human or man.

Those who are left, [will] they not follow them to the grave?

Are there no hurt people among them?

And if someone like a viper when they lie in wait [...]"

It appears that the two indicated texts allow us to ultimately disprove Mann's thesis. The contradiction which was analysed by Mann and results from Zarah ben Natan's information that Yișhaq ben Avraham had been dead for 32 years, can probably be explained by textual corruption. There is likelihood that in the original note the diacritical marks were above shin, pe and waw of the second word (שף לעלמו), which gives us the number 386, that is, the year 1626 (32 years after 1594). Therefore, Zarah ben Natan's letter to Yosef Delmedigo should then be dated 1626 not 1620, and the date of Zarah ben Natan's birth should be determined as 1585/6.

\footnotetext{
${ }^{30}$ Cf. fol. 151 r: בשבת שמחת תורה בשנת אריתי מורי עם בשמ"י לפ"ק \פה בק"ק טרוקי.

${ }^{31}$ Cf. Isa. 58:7.

${ }^{32} 1593 / 1594$ in the Gregorian calendar.
} 
Assuming as certain that Ișhaq ben Avraham died in 1593/4 (and was born 60 years earlier, i.e. in 1533/4), we can presume that Yosef ben Mordekhay Malinowski had to be at least 18 years old at that time (Zarah ben Natan reports that he became his teacher immediately after Yișhaq ben Avraham's death ${ }^{33}$ ). If so, he would have been 34 years old in 1610. Consequently, the year 1610 seems terminus ad quem for his life.

It seems that a crucial argument for the dating of Noah ben Yeshaya's letter is the NLR Evr II a 71a manuscript, entitled Seper ham-Melisa. This manuscript consists of 43 leaves which include a collection of works by Noah ben Yeshaya. This was previously discussed by Israel Zinberg in his Toldot Siprrut Isra'el. ${ }^{34}$ This manuscript is not an autograph. The palaeography suggests it might be dated to the first half of the $18^{\text {th }}$ century. Two dates were noted in the manuscript, the former on fol. 1or (bottom pagination): Monday, $26^{\text {th }}$ Menahem, 5363 from the creation of the world, ${ }^{35}$ and the latter on fol. $43 \mathrm{r}$ : Wednesday, $19^{\text {th }}$ shevat 5363 from the creation of the world. ${ }^{36}$ These notes indicate that the first part of the text (i.e. 1r-10r) was created later, at the beginning of August 1603, whereas the other earlier one (i.e. 10r-43r), at the end of January 1603. The part which is finished by the second colophon, namely from fol. 1 or to fol. 34 r, is particularly significant. It begins with the words: "The speech of Noah, son of my lord and father, esteemed Yeshaya, let the one who walks uprightly enter into peace and rest on his bed (cf. Isa. 57:2)". The contents of the work clearly indicate that we are dealing with the work mentioned in letter no. 124, i.e. "Ketav ha-'emet ve-had-derash", which was to be sent to Yosef ben Mordekhay Malinowski. This text, partially written in a poetic form, is Noah ben Yeshaya's account of the situation in the Karaite community of Birże in the early 1600 . Yosef ben Mordekhay is the recipient of the text. On fol. 19r-19v, we read:

ראיתי בבית יוסף נין יוסף מבין דבר ואיש תאר וה' עמו וכל אשר יפנה ירשיע והצלחתי

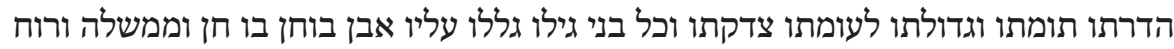

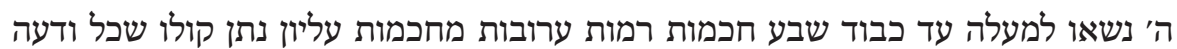

\footnotetext{
${ }^{33}$ Cf. Seper 'Elim, in the Odessa edition from 1864, p. 4: ... דרך ככב יוסף מתחת כנפי יצחק ויהי מקץ שנה השקוני יין ענושי.

34 ZINBERg 1958: 385-388.

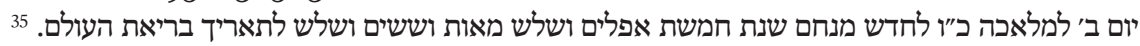

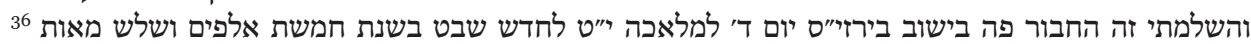
ששים ושלש לתאריך בריאת העולם.
} 
לגאון שמהו צפי תפארת עמידתו על שכיות החמדה הקדימני השקני מי סמי התבונה ועוד

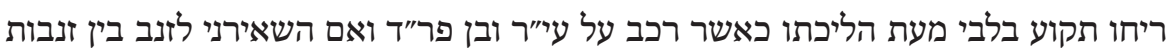

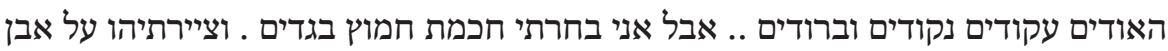

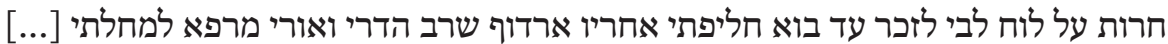

"I saw in the house of Yosef, great-grandson of Yosef - the one who understands the word, a handsome man, and the Lord is with him (cf. 1 Sam. 16:18), and wherever he turns he is victorious (1 Sa 14:47), and his success is his glory - his integrity, greatness, next to his righteousness. And all his peers rolled a granite stone on him (Isa. 28:16). In him there is grace and domination. The Lord's spirit raised him up to the circle of the seven highest pleasant wisdoms. By the powers of the Most High he uttered his voice of discretion and knowledge. For pride he set him. The beauty of adornment is the pride of his name. He stood upon the beautiful pictures (Isa. 2:16). He accepted me and gave me the aromatic water of understanding to drink. His scent is still in my heart, from his leaving, when he rode a donkey-foal and a mule (cf. Zech. 9:9). ${ }^{37}$ Although he left me, like a tail, like smouldering tails, ${ }^{38}$ striped, spotted and piebald (cf. Gen 31:10-12), I chose wisdom and crimson garments (Isa. 63:1). I drew him on a carved stone and on the table of my heart (Prov. 7:3), to commemorate. Until my turn comes, I will follow him, for rav, my light and my glory, is the healing for my sickness [...].

In the next part, Noah turns directly to Yosef many times. For example, he writes on fol. $21 \mathrm{r}-21 \mathrm{v}$ :

[...] ולך הרב אשלח בשלח לקראת מנאצי ולא אסתיר ואתיר כל אגודות מוטה למטה

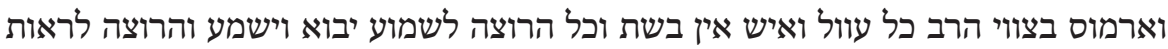

${ }^{37}$ A parallel note in Bet Zerubbabel of Yehuda ben Zerubbabel: (Abk 3, fol. 161v, 5-10) "[...] And this also added to my sadness to my sorrow, and grief to my grief, that our honourable great teacher, ribbi Yosef, scholar, son of our honourable great teacher ribbi Mordekhay, the martyr, may he rest on his bed in peace, a man who has the Lord's spirit in him, left his house and abandoned his legacy, he saddled up his donkey and left because of the evil of the inhabitants of his town.[...]" Cf. Mann 1935: 1193-1195.

${ }^{38}$ Play on words. The translation has been adapted to fit the context. The meaning based on Isa. 7:4: "smoking brands". 


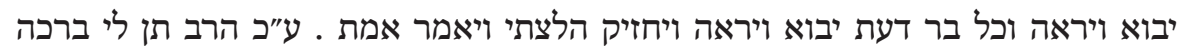

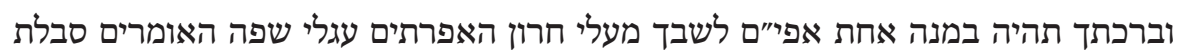

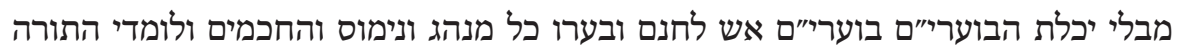

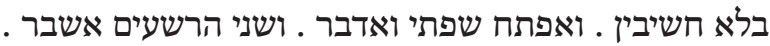

"[...] and I will send to you, rav, sending against those who spurned me, and I will not hide anything, I will undo all the bands of the yoke (cf. IsA. 58:6) downwards and trample, on the command of rav, all indignity and a man of no shame. And everyone who will want to, will be able to come and listen. And everyone who will want to see, will be able to see. Each enlightened one will be able to come and see. He will hold my rhetoric. And he will speak the truth. Thus, rav, give me your blessing. And your blessing will be like a double portion (cf. 1 Sam 1:5), so that you draw out your anger towards me. The Ephrathites, ${ }^{39}$ stutterers, who say sibboleth (cf. Judg. 12:6), unable (differently), who burn, burn fire in vain, and burned all ways and customs. They do not regard sages and scholars of the Torah. I will open my mouth and speak. I will knock out the teeth of sinners".

Noah writes about the situation in Birże. The local hazzan, who had been chosen shortly before, is an object of very emotional accusations, and so are his supporters, who play the dominant role in the community. Individual persons are not named but are given pseudonyms. Noah accuses the incumbent hazzan of lacking the knowledge and skills required of a hazzan, breaking the law and indecent behaviour (e.g. lighting a fire and strolling on Shabbat, insult, anger, spitting in the synagogue, various violations of the rules of liturgy, a lack of sufficient knowledge of the holy language, etc.). Indeed, the content of the text gives us certainty that we are dealing with the work mentioned in Noah's letter, i.e. "Ketav ha-'emet ve-had-derash". In this context, it is important that according to the information in the colophon on fol. $43 \mathrm{r}$ the work was completed in January 1603. It can be deduced from its content that at that time Yosef ben Mordekhay left Troki and moved to Łuck, but was definitely alive (he is also mentioned in the first part, finished in 1603).

The data above prove that the letter from Noah ben Yeshaya to Yosef ben Mordekhay (Evr I Dok II 49) should be dated most probably to 1601 or 1602.

\footnotetext{
${ }^{39}$ A term used to describe members of the Karaite community in Birże.
} 
Unfortunately, we are not able to settle the problem of the date in this letter definitively. Dates from the year 5363 in preserved Karaite documents are not coherent. The calendar used by Noah ben Yeshaya in Birże probably differed from the one in Troki. Moreover, we were not able to find any dated Karaite documents from the year 5362 to contrast the date in the letter of Noah ben Yeshaya with it. ${ }^{40}$ The date 1602 seems to be favoured if we consider that "Ketav ha-'emet ve-had-derash", which was mentioned in letter no. 124, was completed in January 1603. Historical data on the Second Swedish War of 1600-1611 indicate that in the period under consideration, Birże played an active role in the war. The hetman Krzysztof Radziwill, "Piorun" ("the Thunderbolt"), the owner of Birże, was one of the commanders in chief of the Polish-Lithuanian army during the campaign of $1601-1603 .{ }^{41}$ In the light of the presented data, it seems most probable that Yosef ben Mordekhay died after August 1603, but not later than 1610 (if we assume that he was at least 18 years old in 1594). Therefore, his life can thus be generally established as dating from 1569 to 1610 .

\section{Bibliography}

BALCEREK, Mariusz. 2012. Księstwo Kurlandii i Semigalii w wojnie Rzeczypospolitej ze Szwecją $w$ latach 160o-1629. Wydawnictwo Poznańskie: Poznań.

BARDACH, Juliusz. 1990. Żydzi w Birżach radziwiłłowskich w XVII-XVIII wieku. Przeglad Historyczny LXXXI, 1-2, 199-220.

Bezekowicz, Yehuda, Ișhaq-Boaz Firkowicz. 1909. Tehillot Isra'el. Tosafot li-Tefillot haq-Qara'im. Berdyczew.

\footnotetext{
${ }^{40}$ Among the other documents from the Firkowicz collection, there is only one dated 5363, i.e. Evr I Dok II 19 (MANN 1935: 792). It is a deed from Troki which bears the date Wednesday (yom dalet), $18^{\text {th }}$ of Tevet, 5363. This date is in accordance with the Rabbinical calendar for the year 5363 . However, the $25^{\text {th }}$ of Tishri 5363 , according to this calendar, falls on Thursday, not on Sunday (as in Evr I Dok II 49, fol. 1v). In the Rabbinical calendar, the $25^{\text {th }}$ of Tishri falls on Sunday in the preceding year, i.e. in 5362. If the date in Evr I Dok II 49 was in accordance with the Rabbinical calendar, the letter of Noah ben Yeshaya would have to be dated to 5362 , i.e. to October 1601 in the Gregorian calendar. However, we are not able to settle this, as we have no comparative material from this year. Moreover, it is noteworthy that the two dates in NLR Evr II a 71a are not consistent with the calendar of Troki as evidenced in NLR Evr I Dok II, 19. It suggests that the calendar of the Karaite community in Birże for 5363 was not coherent with the calendar (or calendars) of other Karaite communities.

${ }^{41}$ Podhorodecki 1982: 56-113; BalcereK 2012: 75-78; Wimmer 2013: 21-28.
} 
FüNN (Finn), Shemuel. Y. 1867-1868. Pletat sofrim. Mi-Kitve harav rabbi Yosef Shlomo Delmedigo, zikhrono li-vrakha. Hakarmel 6, 358-359, 366-367, 390-391, 402-404. GĄSIOROwsKI, Stefan. 2008. Karaimi w Koronie i na Litwie w XV-XVIII wieku. Wydawnictwo Austeria: Kraków-Budapeszt.

Geiger, Abraham. 1853. Isaak Troki. Ein Apologet des Judenthums am Ende des sechszehnten Jahrhunderts. Verlag von Joh. Urban Kern: Breslau.

Komlosh, Yehuda, and Golda Akhiezer. 2007. Zerah ben Nathan of Troki. Encyclopaedia Judaica. Eds. Michael Berenbaum and Fred Skolnik. Vol. 21. $2^{\text {nd }}$ ed. Detroit: Macmillan Reference USA. 513. 22 vols. Gale Virtual Reference Library. Gale. Hebrew University of Jerusalem.

[Malinowski, Yosef ben Mordekhay]. 1830. Qișșur Inyan haš-Šeḥita. ANTON Edlem von SCHMID: Wien, fol. 28 verso - 33 verso.

Menashe ben Israel. [1643]. Sep̄er ha-'Elef Lekha. Hibbro he-hakham ham-muvhaq kewod ma'alato ha-rav ribbi Josef, zkikhron șaddiq li-vrakha, ben kevod ma'alato ribbi Mordekhay haq-qadosh, haš-Šem yiqqom damo. Amsterdam.

Nemoy, Leon. Troki, Isaac Ben Abraham. 2007. Encyclopaedia Judaica. Eds. Michael Berenbaum and Fred Skolnik. Vol. 20. $2^{\text {nd }}$ ed. Detroit: Macmillan Reference USA. 155-156. 22 vols. Gale Virtual Reference Library. Gale. Hebrew University of Jerusalem.

Podhorodecki, Leszek. 1982. Jan Karol Chodkiewicz 156o-1621. Wydawnictwo Ministerstwa Obrony Narodowej: Warszawa.

Szyszman (Shishman), Yaaqov Y. (ed.). 1891. Siddur hat-Tefillot haq-Qara'im. Volume I. Tipografiya Topografia L.L. Maca: Vilna.

Szyszman (Shishman), Yaaqov Y. (ed.). 1892a. Siddur hat-Tefillot haq-Qara'im. Volume III. Tipografiya Topografia L.L. Maca: Vilna.

Szyszman (Shishman), Yaaqov Y. (ed.). 1892b. Siddur hat-Tefillot haq-Qara'im. Volume IV. Tipografiya Topografia L.L. Maca: Vilna.

Wimmer, Jan. 2013. Polska-Szwecja. Konflikty zbrojne w XVI-XVIII wieku. Wydawnictwo Napoleon V: Oświęcim.

Wolfius, Joanne Christophorus, Jacobi Triglandii. 1714. Notitia Karaeorum ex Mardochaei, Karaei recentioris, Tractatu Haurienda, quem ex ms. cum versione Latina notis et praelatione de Karaeorum rebus Scriptisque editit Joannes Christophorus Wolfius, Hebr. et oriental. lingg. prof. publ. Accedit in calce Jacobi Triglandii. Differatio de Karaeis cum Indicibus variis recufa. Hamburgi et Lipsiae. ZINBERG, Israel. 1958. Toldot Sifrut Israel. Vol. 3. Ha-Merkaz ha-Tarbuti ba-Mamlakha ha-'Otomanit/ Ha-Merkaz ha-Tarbuti ha-Ashkenazi-Polani. Sifriyat Po'alim, Hotsa'at Joseph Sharbrak: Te Aviv, 385-388. 
Piotr Muchowski is a professor in the Department of Asian Studies at the Adam Mickiewicz University in Poznan (in the section of Hebrew, Aramaic and Karaite Studies). His recent research focuses on the literature of the Karaites in the Polish-Lithuanian Commonwealth. His latest publication is the book Folk Literature of the Polish-Lithuanian Karaites: Abkowicz 3 Manuscript, Part 2 (Editions Suger Press, Revue Européenne des Etudes Hébraïques: Paris 2013).

Arie Yariv, studied at Bar-Ilan University, Ramat-Gan, Israel, and graduated from the Faculty of Arabic Language and Literature (1978) and the Faculty of Hebrew and Semitic Languages (1981). His Ph.D. dissertation The Karaites in the Polish-Lithuanian Commonwealth: Communal Institutions and Their Relations with the Rabbinic Jews, the Karaite Diaspora, and Other Minorities in the Country was submitted in the School of Jewish Studies at Tel Aviv University in 2014. 
12

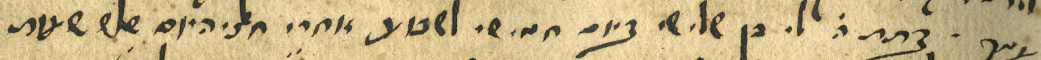

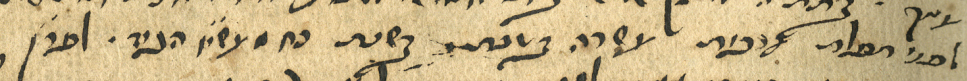

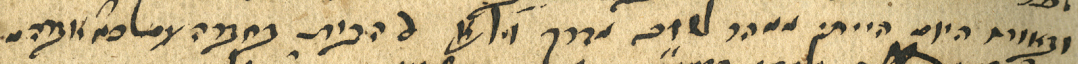

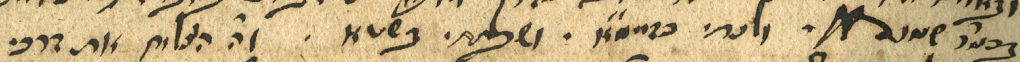

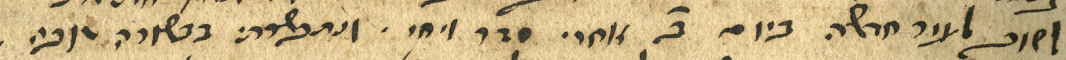
mives/की

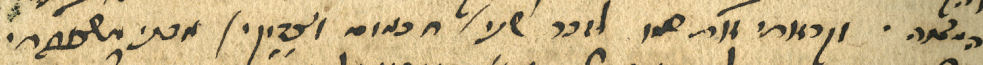

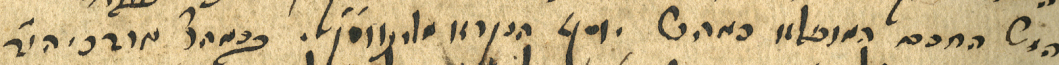

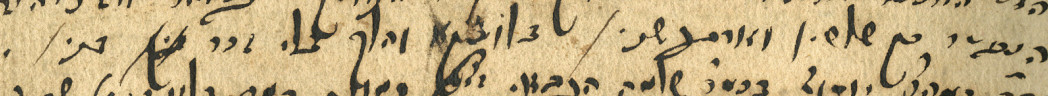

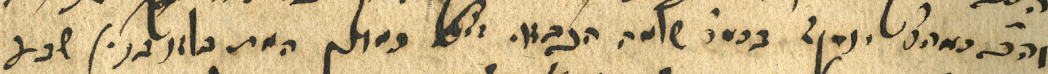

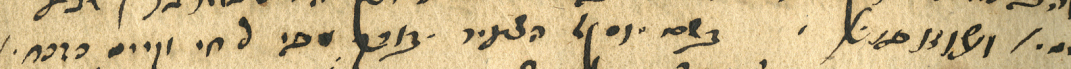
-

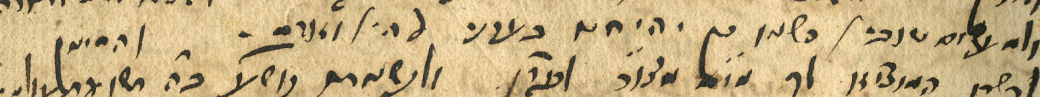

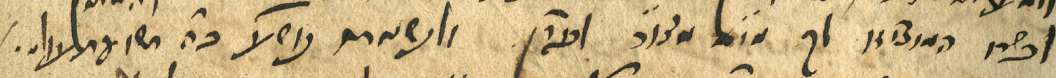

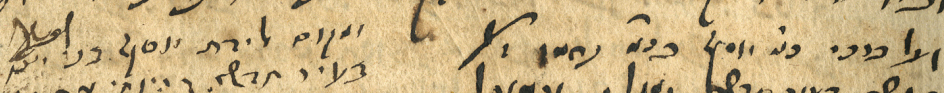

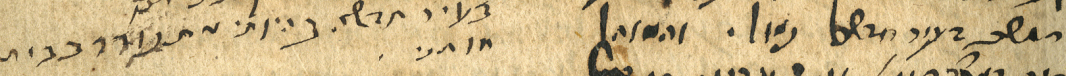

a gntzlesh

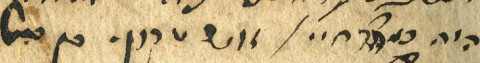

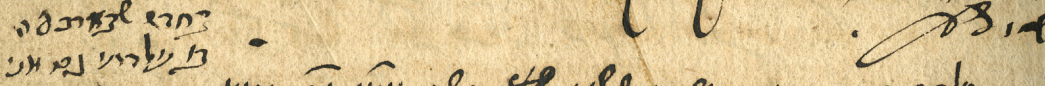

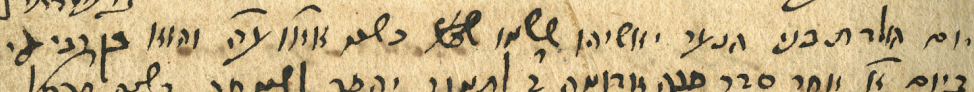

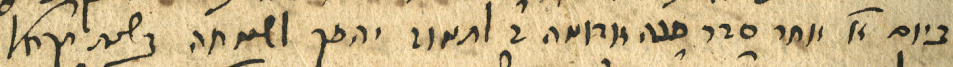

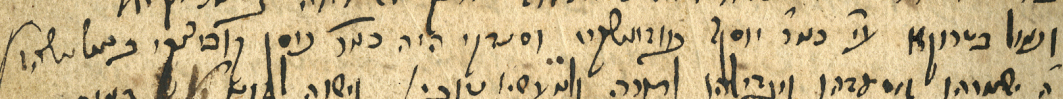

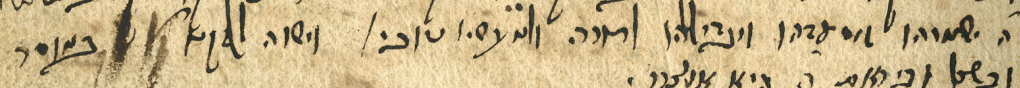

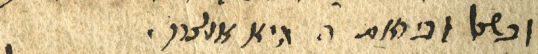

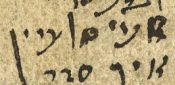
$17209^{116}$ axisyol

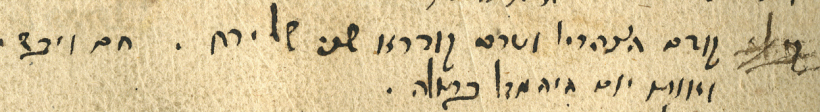

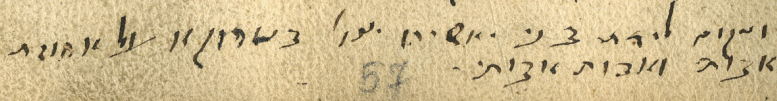

Fig. 1 NLR Evr I 732, fol. 56 recto 


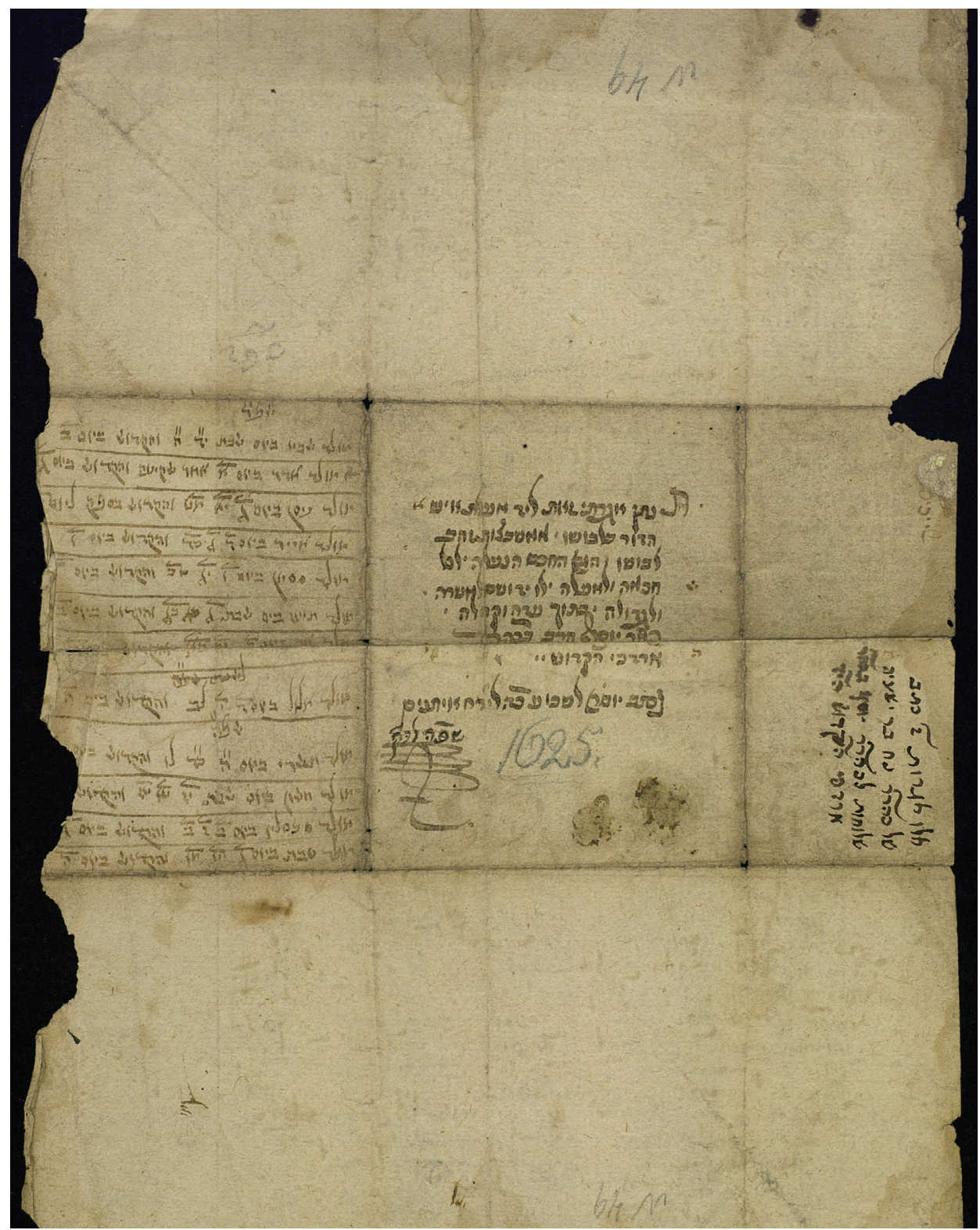

Fig. 2 NLR Evr I Dok II, 49, fol. 1 verso 